\title{
Research of the Motivational Component of Professional Activity of Employees of the Security and Defense Sector
}

\author{
Olena Fedorenko ${ }^{1, *}$, Victoria Dotsenko ${ }^{1}$, Oleh Petruk ${ }^{2}$, Viktoriia Bedan ${ }^{3}$, Andriy Vikhtiuk ${ }^{4}$, \\ Olena Kudermina ${ }^{5}$ and Svitlana Izbash $^{6}$
}

\author{
${ }^{1}$ Kharkiv National University of Internal Affairs, Kharkiv, Ukraine \\ ${ }^{2}$ Yaroslav Mudryi National Law University, Kharkiv, Ukraine \\ ${ }^{3}$ National University "Odessa Law Academy", Odessa, Ukraine \\ ${ }^{4}$ Administration of the State Border Guard Service of Ukraine, Directorate of Work Organization, Planning and \\ Control, Kyiv, Ukraine \\ ${ }^{5}$ National Academy of the Internal Affairs of Ukraine, Kyiv, Ukraine \\ ${ }^{6}$ National Academy of the National Guard of Ukraine, Kharkiv, Ukraine
}

\begin{abstract}
The paper presents a study of the characteristics of the professional motivation of security and defense workers and reveals the relationship between motivation and individual psychological qualities and people's attitudes to various aspects of reality in police officers and servicemen. The logical relationship of correlations between work motivators and personality qualities and the attitude of servicemen and police officers to various aspects of reality is found, which will help the leader (psychologist) to increase efficiency.

The article says that adequate and timely stimulation of activities based on personal qualities and attitudes to various aspects of the life of security and defense workers will prevent negative factors (development of emotional burnout, deviant behavior, negative mental states, etc.) and successfully correct them.

The article aims to study the statistical motivation of security and defense workers and determine the relationship between motivation and individual psychological qualities and people's attitudes to various aspects of reality in police officers and servicemen.
\end{abstract}

Keywords: Servicemen, motivation, police officers, professional activity, attitude, qualities.

\section{INTRODUCTION}

The current state of life plus the integration processes taking place in Ukraine contribute to the growth of requirements for the level of professionalism of specialists in the field of security and defense. This is primarily due to the specifics of their professional activities, which are extreme and risky (national security and defense, public safety and order; use of firearms; repulse and deterrence of aggression; being in situations involving death, injury, trauma; stay in hostages or negotiating with criminals, etc.) and aims to protect the rights and freedoms of citizens. Peculiarities and specifics of the professional activity of specialists of the Armed Forces of Ukraine and the National Police of Ukraine place high demands on business, moral and professional qualities of their personality. But the effectiveness of the professional activities of specialists in the security and defense sector requires not only the development of certain qualities and abilities of their personality but also

*Address correspondence to this author at the Kharkiv National University of Internal Affairs, Kharkiv, Ukraine; Tel: +380506061778;

E-mail:maxnik8888@gmail.com interest in work, interest in achieving results, and satisfaction with the work performed.

The integration processes taking place in Ukraine contribute to the growth of requirements for the level of professionalism of specialists in the field of security and defense. For example, the authors single out the following: the content of activities, success, recognition of the employee as a person, the possibility of promotion, etc. (llyin EP, 2008; Richie and Martin, 2009; Safin OA, 2014). Note that the motivational sphere of a person is dynamic; motivation may increase or decrease, motivators change. Therefore, the problem of diagnosis and monitoring of the positive impact of motivators on the professional activities of security and defense workers does not lose its relevance and needs new solutions taking into account the dynamics of change in modern life. Solving the above problems can give us an idea of what helps a specialist whose professional activity is carried out in the field of law enforcement and national security and defense to effectively solve official tasks, and what negatively affects which factor needs to be eliminated, which management methods used to improve 
employee motivation and thus increase the effectiveness of its activities

Authors such as O. Bandurka, L. Balabanova, V. Barko emphasized that motivation to serve and perform a professional activity is one of the factors that determine the effectiveness of performance of official tasks and ensures the formation of stress resistance in employees of the security and defense sector. D. Kobzin, I. Prykhodko, O. Safin, V. Sobolev, O. Stolyarenko, V. Osyodlo, O. Timchenko, O. Tsilmak, S. Yakovenko, and others. In one of the latest surveys, a sample of 1,083 police officers from various units (criminal police, pre-trial investigation bodies, district police officers, patrol police) determined that the main motivators of their activities are: the desire for interesting and socially useful work; the need for selfimprovement; the desire to receive a high salary; the need for public recognition; in a clear structuring of work (Smirnova OM, 2018). Despite the significant number of studies of the professional motivation of both servicemen and law enforcement officers, unfortunately, they lack unanimity in determining the motivational profile of employees; comparative analysis of the main motivators of activity according to the criteria of age, gender, subdivision; all-Ukrainian research.

Foreign authors (J. Atkinson, B. Weiner, F. Herzberg, D. McClelland, R. Nigard, and others) have also repeatedly noted the existence of a close relationship between performance and motives for achievement, which is manifested in: setting and achieving complex goals; taken responsibility for their own lives and success; raising the level of claims; compliance of motivation with personal capabilities, etc. Domestic and foreign authors unanimously emphasize that understanding the motives of employees and the factors that determine them allows the head (manager) to increase the efficiency and rational use of staff.

The aim of the article is to study the statistical motivation of security and defense workers and to determine the relationship between motivation and individual psychological qualities and people's attitudes to various aspects of reality in police officers and servicemen.

To achieve this goal, the following research objectives were set:

to determine and compare the motivational profile of the personality of police officers and servicemen; to compare indicators of motivators of the behavior of servicemen and police officers with indicators of their individual psychological qualities of the person;

- to find out the relationship between the motivators of the behavior of servicemen and police officers and the peculiarities of their attitude to different aspects of reality.

A set of methods was used to solve the set tasks: theoretical methods - analysis, synthesis, and generalization of psychological literature on the research problem; empirical methods psychodiagnostic test methods, including: method "Study of the motivational profile of the individual" (authors S. Richie, P. Martin) to determine the satisfaction of 12 basic human needs in the process (Richie and Martin, 2009); method "Modified personality card" (author K. Platonov) - to determine the professionally important and personal qualities of the individual. It is built on the principle of polar profiles and includes 93 individual psychological properties and attitudes of the individual. Each property is evaluated on a 10-point scale (https://studfile.net/preview/ 5263788/page:100/). Mathematical and statistical data processing was performed using software packages "SPSS 22.0" and "Microsoft Office Excel 2003", which provided the calculation of variational Statistics: Student's t-test for independent samples to identify statistically significant differences between the average values of comparable indicators between study groups.; Spearman's rs correlation analysis between two variable-related correlations was used to establish the density of relationships between the studied indicators.

\section{METHODS}

The experiment was of 109 employees of the security and defense sector, which were divided into two groups. The first group of subjects - 57 servicemen who had just joined the Armed Forces of Ukraine, the length of service at the time of testing was three months $(52.3 \%)$. The second group of the study - 52 police officers who were first hired in the criminal police, service experience - 2 months (47.7\%).

First, using the method of "Study of the motivational profile of the individual" (authors S. Richie, P. Martin), we diagnosed the relevance and significance of the twelve needs for employees of the security and defense sector and identified their motivational profile. 
Table 1: Features of Motivation of Professional Activity of Employees of the Security and Defense Sector, (xcp $\pm \sigma)$

\begin{tabular}{|c|c|c|c|c|}
\hline Need & 1 group & 2 group & $\mathbf{t}$ & p \\
\hline High earnings and material incentives & $37.49 \pm 13.84$ & $35.17 \pm 12.77$ & 0.91 & 0.37 \\
\hline Comfortable working conditions & $25.54 \pm 11.81$ & $22.85 \pm 12.31$ & 1.17 & 0.25 \\
\hline Structuring labor & $30.04 \pm 10.88$ & $37.35 \pm 12.40$ & 3.28 & 0.001 \\
\hline Social contacts & $26.26 \pm 14.04$ & $32.56 \pm 43.55$ & 1.03 & 0.30 \\
\hline Stable relationships & $25.49 \pm 10.76$ & $23.85 \pm 7.69$ & 0.91 & 0.36 \\
\hline Public recognition & $29.35 \pm 8.99$ & $31.79 \pm 9.56$ & 1.37 & 0.17 \\
\hline Achieving complex goals & $33.49 \pm 9.34$ & $34.90 \pm 8.19$ & 0.84 & 0.40 \\
\hline Influence and power & $26.75 \pm 8.25$ & $20.83 \pm 9.35$ & 2.93 & 0.05 \\
\hline Diversity and stimulation & $36.46 \pm 15.48$ & $28.00 \pm 8.73$ & 3.47 & 0.001 \\
\hline Creativity & $29.79 \pm 9.42$ & $27.23 \pm 9.75$ & 1.39 & 0.17 \\
\hline Self improvement & $30.46 \pm 9.58$ & $34.52 \pm 8.50$ & 2.33 & 0.02 \\
\hline Interesting, socially useful work & $32.98 \pm 12.52$ & $39.40 \pm 9.97$ & 2.88 & 0.05 \\
\hline
\end{tabular}

As can be seen from Table $\mathbf{1}$, the dominance of servicemen (1 group) was determined by the following needs: high earnings and material incentives (37.49 \pm 13.84), diversity and stimulation (36.46 \pm 15.48), achievement of complex goals (33.49 \pm 9.34), interesting, socially useful work $(32.98 \pm 12.52)$. The least important for servicemen are the needs for stable relationships $(25.49 \pm 10.76)$, comfortable working conditions (25.54 \pm 11.81), social contacts (26.26 \pm $14.04)$, and influence and power (26.75 \pm 8.25$)$.

It was found that the most significant needs for police officers are: interesting, socially useful work (39.40 \pm 9.97), labor structuring (37.35 \pm 12.40$)$, high earnings and material incentives (35.17 \pm 12.77), achieving complex goals $(34.90 \pm 8.19)$. The least significant for police officers are the needs for influence and power (20.83 \pm 9.35), comfortable working conditions $(22.85 \pm 12.31)$, stable relationships (23.85 $\pm 7.69)$, and creativity $(27.23 \pm 9.75)$.

A number of statistically significant differences were found, namely (see Table 1): the need for interesting, socially useful work is statistically significant $(p \geq 0.05)$ more relevant for police officers $(39.40 \pm 9.97)$ than for servicemen (32.98 \pm 12.52$)$; the need to structure labor is statistically significant $(p \geq 0.001)$ more important for police officers $(37.35 \pm 12.40)$ than for military personnel (30.04 \pm 10.88$)$; the need for diversity and stimulation was statistically significant $(p \geq 0.001)$ less important for police officers $(28.00 \pm 8.73)$ than for military personnel (36.46 \pm 15.48$)$; the need for influence and power is statistically significant $(p \geq 0.05)$ has a low value for police officers $(20.83 \pm 9.35)$ compared to the indicator of this need for servicemen $(26.75 \pm 8.25)$.

As a result, we can state that the professional activity of servicemen is motivated by high earnings and material rewards, diversity, the opportunity to learn something new, set bold, difficult goals and achieve them, the desire to do everything yourself, interesting, socially useful work. Police officers are motivated primarily by interesting, socially useful work, and secondly by the organization, predictability, feedback, and information that allows them to evaluate the results of their work. In addition, police officers are motivated by high earnings and the need to set bold, challenging goals and achieve them in a competitive process.

Using the method of "Modified identity card" (author K. Platonov), it was determined that the military have the following individual psychological qualities (given in the order of importance, from largest to smallest): 1) imaginative, volitional; 2) psychomotor; 3) language; 4) attentional; 5) sensory-perceptual, mental; 6) communicative; 7) mnemonics; 8) emotional. And among the priority of attitudes of servicemen prevail: 1 ) to the team, to the order, to the new; 2) to criticism, to work, to failures; 3 ) to public life, to courage; 4) to money, to the future, to health; 5) to others, to guardianship and instructions; 6) to himself, to others; 7 ) to the rules and the law.

During the self-assessment, police officers found out that they have the following individual psychological qualities of personality: 1) language; 2) volitional, sensory-perceptual; 3) imaginative; 4) mental; 5) communicative; 6) mnemonic, attentional; 7) 
psychomotor; 8) emotional. In relation to various aspects of reality, police officers are dominated by: 1) themselves, the future; 2 ) to others, to the new; 3 ) to the order, to the rules and the law; 4) to work, to courage, to one's health; 5) to money, to guardianship and instructions; 6 ) to failures.

For S.L. According to Rubinstein, the motives of behavior come into action and are fixed by fixing in character. Dominant, stable motives of behavior are potential future individual psychological qualities of character, motivation-for example, responsibility, curiosity, persistence, sociability, etc. The author sees the way of character formation through the formation of appropriate motives for behavior and the organization of actions aimed at consolidating them (Rubinstein SL, 2002). Therefore, the next stage of our study was to determine the relationship between indicators of individual psychological qualities of the individual and motivators of behavior in the security and defense sector (lasechko, et al., 2020, p. 1169-1174; lasechko et al., 2020, p. 844-849; lasechko et al., 2020, p. 430432).

In servicemen, statistically significant relationships were found between the indicators of seven motivators with indicators of eight individual psychological qualities (see Table 2). Thus, the indicator of the motivator of comfortable working conditions is statistically significant $(p=0.001)$ forms a number of inverse correlations with indicators of individual psychological qualities, namely with: attentional $\left(r_{p}=-0.532\right)$, mnemonic $(r p=-0.536)$, imaginative $\left(r_{p}=-0.466\right)$, mental $\left(r_{p}=-0.426\right)$, emotional $\left(r_{p}=-0.351\right)$, volitional $\left(r_{p}=-0.458\right)$, communicative ( $r p=-0.395)$, verbal $\left(r_{p}=-0.324 ; p=\right.$ $0.05)$. The connection between motivation and qualities is two-way. Therefore, we can assume that these qualities of servicemen do not contribute to the development of their motivation for good, comfortable working conditions and, conversely, motivation does not develop the appropriate inclinations. The indicator of the motivator of social contacts statistically significantly forms inverse correlations with attentional $\left(r_{p}=-0.316 ; p=0.05\right)$, mental $\left(r_{p}=-0.345 ; p=0.001\right)$, emotional $\left.\left(r_{p}=-0.275 ; p=0\right), 05\right)$ and language $\left(r_{p}=\right.$ $0.370 ; p=0.001$ ) indicators of individual psychological qualities. That is, the motivation of activities with numerous social contacts will not contribute to the development of the above qualities in the military.

Motivation of activity by stable relationships statistically significantly forms direct correlations with attentional ones $\left(r_{p}=0.335 ; p=0.05\right)$, Thinking $\left(r_{p}=\right.$ $0.294 ; p=0.05)$, Volitional $(r p=0.315 ; p=0.05)$, Communicative $\left(r_{p}=0.335 ; p=0.05\right)$ and Linguistic $\left(r_{p}\right.$ $=0.370 ; \mathrm{p}=0.001)$ indicators of individual psychological qualities. That is, the desire of servicemen to work in conditions of trust, favorable work and personal relationships is associated with the ability to think, communicate, attentive and strongwilled. The indicator of motivation to achieve complex goals forms statistically significant direct correlations with attentional $\left(r_{p}=0.565 ; p=0.001\right)$, Mnemonic $\left(r_{p}=\right.$ $0.307 ; p=0.001)$, Thinking $\left(r_{p}=0.264 ; p=0.05\right)$, Volitional $\left(r_{p}=0.359 ; p=0.001\right)$ and Linguistic $\left(r_{p}=\right.$ $0.266 ; p=0.05$ ) indicators of individual psychological qualities. In other words, servicemen who set complex goals and strive to achieve them develop attentiveness,

Table 2: The Nature of the Relationship between Indicators of Behavioral Motivators and Indicators Individual Psychological Qualities of the Personality of Servicemen, (rs)

\begin{tabular}{|c|c|c|c|c|c|c|c|c|}
\hline 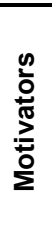 & 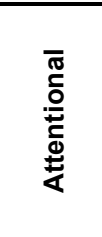 & $\begin{array}{l}\frac{0}{\Xi} \\
\frac{0}{\varepsilon} \\
\stackrel{\Xi}{\Sigma}\end{array}$ & 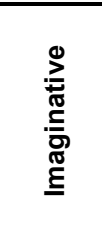 & 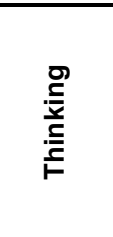 & 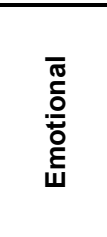 & 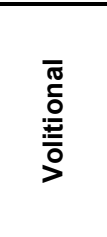 & 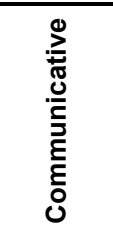 & 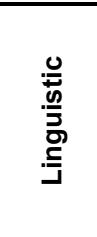 \\
\hline 2 & $-.532^{\star *}$ & $-.536^{\star *}$ & $-.466^{\star *}$ & $-.426^{\star *}$ & $-.351^{* *}$ & $-.458^{\star *}$ & $-.395^{\star *}$ & $-.324^{*}$ \\
\hline 4 & $-.316^{*}$ & - & - & $-.345^{\star *}$ & $-.275^{*}$ & - & - & $-.370^{* *}$ \\
\hline 5 & $.335^{*}$ & - & - & $.294^{*}$ & - & $.315^{\star}$ & $.377^{\star *}$ & $.337^{*}$ \\
\hline 7 & $.525^{\star *}$ & $.307^{*}$ & - & $.264^{*}$ & - & $.359^{* *}$ & - & $.266^{\star}$ \\
\hline 10 & $.262^{*}$ & $.383^{* *}$ & $.366^{* *}$ & - & - & - & - & - \\
\hline 11 & - & - & - & $.292^{*}$ & - & - & - & - \\
\hline 12 & - & $.288^{*}$ & - & $.467^{* *}$ & $.331^{*}$ & - & - & $.343^{* *}$ \\
\hline
\end{tabular}

Note: 2 - comfortable working conditions; 4 - social contacts; 5 - stable relationships; 7 - achieving complex goals; 10 - creativity; 11 - self-improvement; 12 interesting, socially useful work; * $-p \leq 0.05 ;{ }^{*}$ - $p \leq 0.001$. 
memory, thinking, will and language skills. The indicator of creativity motivator has statistically significant direct correlations with attentional ones $\left(r_{p}=\right.$ $0.262 ; p=0.05)$, Mnemonic $(r p=0.383 ; p=0.001$ ), imaginative $(r p=0.366 ; p=0.001)$ qualities. We can say that the desire of servicemen to analyze, comprehend, discover new ways to solve professional problems contributes to the development of their attention, imagination, memory. Direct statistically significant correlation between the motivator of selfimprovement and mental qualities $\left(r_{p}=0.292 ; p=0.05\right)$ indicates the relationship between personal development and thinking abilities of servicemen. The motivator indicator is interesting, socially useful work has four statistically significant direct correlations with mnemonic $\left(r_{p}=0.288 ; p=0.05\right)$, Thinking $\left(r_{p}=0.467 ; p\right.$ $=0.001)$, emotional $\left(r_{p}=0.331 ; p=0.05\right)$ and Linguistic $\left(r_{p}=0.343 ; p=0.001\right)$ qualities. That is, if you organize the activities of servicemen in such a way that it is perceived as interesting and useful, you can promote the development of their language skills, memory, thinking, emotions.

Police officers were found to have a significantly smaller number of statistically significant relationships between motivators and individual psychological qualities than military personnel (see Table 3).

Statistically significant inverse correlations between motivators of clear structuring of work are diagnosed $\left(r_{p}\right.$ $=-0.332 ; p=0.05)$, influence and power $\left(r_{p}=-0.293 ; p\right.$ $=0.05$ ) and psychomotor qualities. It can be assumed that the desire of police officers to organize, order, and control activities, the desire to control others will not contribute to their effective management of motor actions on the basis of self-control. The desire to form and maintain long-term, stable relationships in the workplace has a statistically significant direct correlation with communication skills $\left(r_{p}=0.321 ; p=\right.$ $0.05)$ police officers. The need for recognition by others forms two statistically significant direct correlations with volitional ones $\left(r_{p}=0.313 ; p=0.05\right)$ and communication $\left(r_{p}=0.305 ; p=0.05\right)$ qualities of police officers. Motivation of police officers to avoid routine in professional activities has a direct correlation with psychomotor qualities $\left(r_{p}=0.320 ; p=0.05\right)$.

M.A. Kuznetsov notes in his article that the motive cannot be identified with other phenomena close to it, such as attitudes. The author emphasizes that the attitude to something - is a consequence of the motive, its expression, motive - is the motivation, the reason for the attitude (Kuznetsov MA, 2012; lasechko et al., 2020, p. 1380-1384; lasechko et al., 2020, p. 109-112; lasechko et al., 2020, p. 569-571; Piskunov et al., 2020; lasechko et al., 2019; lasechko et al., 2020, p. 8575-8579). Based on this position, in order to better understand the motives of security and defense workers and their consequences, we have identified the relationship between their motives and attitudes (lasechko et al., 2020, p. 1380-1384; lasechko et al., 2020, p. 109-112; lasechko et al., 2020, p. 569-571; Piskunov et al., 2020; lasechko et al., 2019; lasechko et al., 2020, p. 8575-8579).

As can be seen from Table 4, the desire of servicemen for comfortable working conditions forms a number of statistically significant inverse correlations with indicators of attitude to work. $\left(r_{p}=-0.537 ; p=\right.$ $0.001)$, to others $\left(r_{p}=-0.426 ; p=0.001\right)$, to strangers $\left(r_{p}=-0.287 ; p=0.05\right)$, to material values $\left(r_{p}=-0.418 ; p\right.$ $=0.001)$, to order $\left(r_{p}=-0.475 ; p=0.001\right)$. Attitude to

Table 3: The Nature of the Relationship between Indicators of Behavioral Motivators and Indicators Individual Psychological Qualities of the Personality of Police Officers, (rs)

\begin{tabular}{|c|c|c|c|}
\hline Motivators & $\begin{array}{l}\overline{0} \\
\stackrel{0}{0} \\
\overline{0} \\
\frac{0}{0} \\
\grave{0} \\
0\end{array}$ & 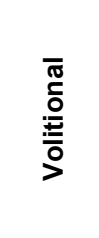 & 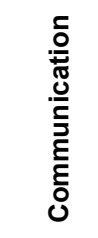 \\
\hline Structuring labor & $-0.332^{*}$ & & \\
\hline Stable relationships & - & & $0.321^{*}$ \\
\hline Public recognition & - & $0.313^{*}$ & $0.305^{*}$ \\
\hline Influence and power & $-0.293^{*}$ & & \\
\hline Diversity and stimulation & $0.320^{*}$ & & \\
\hline
\end{tabular}

Note: ${ }^{*}-p \leq 0.05$ 
work is manifested in respect for work, diligence, or contempt for professional activity. Attitudes toward others and strangers arise in interpersonal contacts. The attitude to material values is shown in ways of earnings and expenses. Attitude to order indicates the presence or absence of such qualities as neatness, honesty, discipline, and so on. It can be argued that the desire for comfortable working conditions in the military is not related to their attitude to the above aspects of reality.

The motivation to communicate with a wide range of people (colleagues, citizens) ranks tenth in the military (26.26 \pm 14.04$)$ and has a number of statistically significant inverse correlations with indicators of attitudes to work $\left(r_{p}=-0.374 ; p=0.001\right)$, to others $\left(r_{p}=\right.$ $-0.313 ; p=0.05)$, to material values $\left(r_{p}=-0.348 ; p=\right.$ 0.001 ), to order ( $r p=-0.277 ; p=0.05)$. Such data may indicate a lack of correlation between the low need to maintain social contacts and the attitude of servicemen to work, others, material values and order (see Table 4).

An indicator of the need for stable relationships at work (25.48 \pm 10.76$)$ least significant for military personnel (12th place) and has three statistically significant inverse correlations with attitudes to work $\left(r_{p}\right.$ $=-0.348 ; p=0.001)$, to others $\left(r_{p}=-0.327 ; p=0.001\right)$, to order $\left(r_{p}=-0.276 ; p=0.05\right)$. In other words, the low need of servicemen in terms of the trust, favorable working, and personal relations in the team is not related to the attitude to work, people around, and order (see Table 4).
It is determined that the motivation to set complex, interesting goals and achieve them forms a number of statistically significant direct correlations with the attitude of servicemen to work. $\left(r_{p}=0.379 ; p=0.001\right)$, to others $\left(r_{p}=0.425 ; p=0.001\right)$, to strangers $\left(r_{p}=\right.$ $0.417 ; p=0.001)$, to public life $\left(r_{p}=0.309 ; p=0.05\right)$, to material values $\left(r_{p}=0.303 ; p=0.05\right)$, to order $(r p=$ 0.388; $p=0.001$ ) (see Table 4).

Motivators of self-improvement have statistically significant direct correlations with the attitude of servicemen to others $\left(r_{p}=0.323 ; p=0.05\right)$ and to material values $\left(r_{p}=0.267 ; p=0.05\right)$. The desire for interesting and useful work directly correlates with the attitude of servicemen to work $\left(r_{p}=0.300 ; p=0.05\right)$, to others $\left(r_{p}=0.330 ; p=0.05\right)$, to criticism $\left(r_{p}=0.284 ; p=\right.$ $0.05)$, to material values $\left(r_{p}=0.325 ; p=0.05\right)$ and to the order $\left(r_{p}=0.320 ; p=0.05\right)$ (see Table 4).

It is determined (see Table 5) that the attitude of servicemen to the new is statistically significant and has direct correlations with the motive of achieving goals $\left(r_{p}=0.319 ; p=0.05\right)$, the desire for creativity in the profession $\left(r_{p}=0.276 ; p=0.05\right)$ and the desire to engage in interesting, socially useful work $\left(r_{p}=0.317 ; p\right.$ $=0.05$ ). Such data may indicate the flexibility of behavior and an optimistic view of the military about the future.

It was found that the attitude to failures forms statistically significant inverse correlations with the desire for social contacts $\left(r_{p}=-0.414 ; p=0.001\right)$ and the need to form and maintain long-term, stable relationships $\left(r_{p}=-0.377 ; p=0.001\right)$ and two direct

Table 4: Features of the Relationship between Indicators of Behavioral Motivators and Indicators of the Attitude of Servicemen to Different Aspects of Reality, (rs)

\begin{tabular}{|c|c|c|c|c|c|c|c|}
\hline Motivators & $\begin{array}{l}\text { r. } \\
\vdots \\
3 \\
0 \\
\circ\end{array}$ & 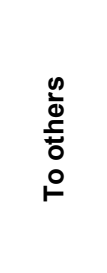 & 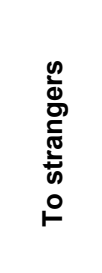 & 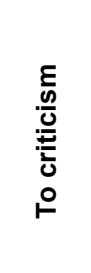 & 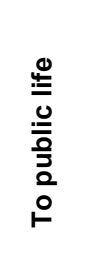 & 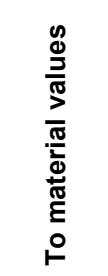 & 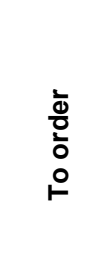 \\
\hline Comfortable working conditions & $-.537^{* *}$ & $-.426^{\star *}$ & $-.287^{*}$ & - & - & $-.418^{* *}$ & $-.475^{\star *}$ \\
\hline Social contacts & $-.374^{* *}$ & $-.313^{*}$ & - & - & - & $-.348^{* *}$ & $-.277^{*}$ \\
\hline Stable relationships & $-.347^{* *}$ & $-.327^{*}$ & - & - & - & - & $-.276^{*}$ \\
\hline Achieving complex goals & $.379^{\star \star}$ & $.425^{\star \star}$ & $.417^{\star *}$ & - & $.309^{*}$ & $.303^{*}$ & $.388^{* *}$ \\
\hline Self improvement & - & $.323^{*}$ & - & - & - & $.267^{*}$ & - \\
\hline Interesting, socially useful work & $.300^{*}$ & $.330^{*}$ & - & $.284^{*}$ & - & $.325^{\star}$ & $.320^{*}$ \\
\hline
\end{tabular}

Note: ${ }^{*}-p \leq 0.05 ;{ }^{* *}-p \leq 0.001$. 
Table 5: Features of the Relationship between Indicators of Behavioral Motivators and Indicators of the Attitude of Servicemen to Different Aspects of Reality, (rs)

\begin{tabular}{|c|c|c|c|c|c|c|c|}
\hline Motivators & 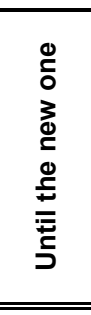 & 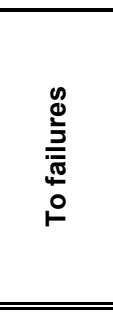 & 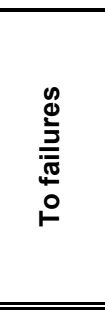 & $\begin{array}{l}\frac{x}{n} \\
\frac{0}{2} \\
\circ\end{array}$ & 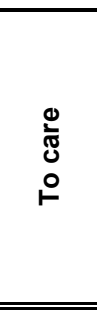 & 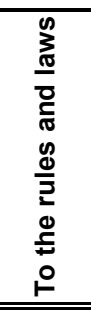 & 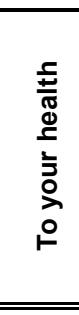 \\
\hline Social contacts & - & $-.414^{* *}$ & $-.305^{\star}$ & - & $-.274^{*}$ & - & $.279^{*}$ \\
\hline Stable relationships & - & $-.377^{* *}$ & - & $-.346^{\star *}$ & - & - & $.280^{*}$ \\
\hline Public recognition & - & - & - & $-.262^{*}$ & - & - & - \\
\hline $\begin{array}{l}\text { Achievement } \\
\text { complex goals }\end{array}$ & $.319^{*}$ & $.312^{*}$ & $.289^{*}$ & $.261^{*}$ & - & - & - \\
\hline Creativity & $.276^{*}$ & - & - & $.262^{*}$ & - & $.312^{*}$ & - \\
\hline Self-improvement & & - & $.266^{*}$ & - & - & - & - \\
\hline Interesting, socially useful work & $.317^{*}$ & $.392^{* *}$ & $.369^{* *}$ & $.296^{*}$ & $.268^{*}$ & - & - \\
\hline
\end{tabular}

Note: ${ }^{*}-p \leq 0.05 ;{ }^{*}-p \leq 0.001$.

correlations with the desire to achieve complex goals $\left(r_{p}=0.312 ; p=0.05\right)$ and engage in interesting, socially useful work $\left(r_{p}=0.392 ; p=0.001\right)$. We can assume that in military personnel, failures are associated with a lack of social contacts or troubles in the relationship and the desire to achieve goals and engage in interesting and useful work despite failures (see Table 5).

The attitude to courage in servicemen forms a statistically significant inverse correlation with the motivator of social contacts $\left(r_{p}=-0.305 ; p=0.05\right)$ and direct correlations with the desire to set and achieve goals $\left(r_{p}=0.289 ; p=0\right.$. 05), the desire to selfimprovement $\left(r_{p}=0.266 ; p=0.05\right)$ and motivation for interesting and useful work $\left(r_{p}=0.369 ; p=0.001\right)$ (see Table 5). That is, to be courageous for servicemen is a restriction of communication and concentration on the achievement of the purpose, aspiration to become better and to be engaged in interesting, useful for people work. It was diagnosed that the attitude to risk in servicemen forms two statistically significant inverse correlations with motivation for stable relationships $\left(r_{p}=\right.$ $-0.346 ; p=0.001)$ and the need for public recognition $\left(r_{p}=-0.262 ; p=0.05\right)$ and three statistically significant direct correlations with the desire to achieve goals ( $r p=$ $0.261 ; p=0.05)$, be creative in the profession $\left(r_{p}=\right.$ $0.262 ; p=0.05$ ) and engage in interesting, useful work $\left(r_{p}=0.296 ; p=0.05\right)$. In other words, to take risks for servicemen is not to need trusting, stable relationships with others, not to seek recognition from society, but to achieve complex goals, generate new ideas, and engage in interesting and useful work. Interestingly, the attitude to guardianship in servicemen forms an inverse correlation with the desire to establish social contacts $\left(r_{p}=-0.274 ; p=0.05\right)$ and a direct correlation with the desire to have interesting and useful work $\left(r_{p}=0.268 ; p\right.$ $=0.05$ ) (see Table 5). The attitude to rules and laws has a direct statistically significant correlation with the desire to be creative in work $\left(r_{p}=0.312 ; p=0.05\right)$. The attitude of servicemen to their own health forms direct correlations with the desire to establish social contacts $\left(r_{p}=0.279 ; p=0.05\right)$ and stable relationships $\left(r_{p}=\right.$ $0.280 ; p=0.05)$. And since the motivation to communicate $(26.26 \pm 14.04)$ and long-term relationships with colleagues $(25.49 \pm 10.76)$ in servicemen have a low level of development, we can assume that they are not inclined to discuss their own health with colleagues.

Analyzing the data in Table $\mathbf{6}$, we should first pay attention to the presence of a much smaller number of statistically significant relationships between motivators of behavior and the attitudes of police officers compared to the military. Thus, the attitude to public life of police officers forms inverse correlations with the desire for high earnings $\left(r_{p}=-0.278 ; p=0.05\right)$ and the desire for diversity and stimulation in work $\left(r_{p}=-0.270\right.$; $p=0.05$ ) (see Table 6). That is, police officers do not see in public life the opportunity to receive high wages and avoid routine. 
Table 6: Features of the Relationship of Indicators of Behavioral Motivators with Indicators the Attitude of Police Officers to Different Aspects of Reality, (rs)

\begin{tabular}{|c|c|c|c|c|c|c|c|}
\hline Motivators & $\begin{array}{l}\stackrel{0}{\leftrightarrows} \\
.0 \\
\frac{0}{0} \\
\vdots \\
0 \\
\circ \\
\circ\end{array}$ & 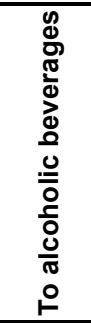 & 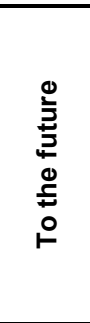 & 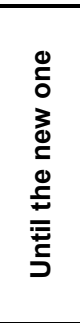 & $\begin{array}{l}\frac{r}{0} \\
\stackrel{0}{2} \\
\circ\end{array}$ & 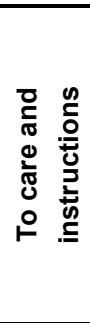 & 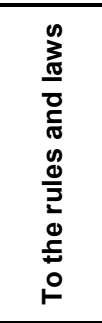 \\
\hline High earnings and financial incentives & $-.278^{*}$ & - & - & - & - & - & - \\
\hline Comfortable working conditions & - & - & - & - & - & - & $-.356^{* *}$ \\
\hline Structuring labor & - & $-.318^{*}$ & - & - & - & & - \\
\hline Public recognition & - & - & - & $.291^{*}$ & $.376^{* *}$ & - & - \\
\hline Influence and power & - & - & $-.321^{*}$ & - & - & - & $-.363^{* *}$ \\
\hline Diversity and stimulation & $-0.270^{*}$ & $.280^{*}$ & - & - & - & - & - \\
\hline Self-improvement & - & - & - & - & - & $-.286^{*}$ & - \\
\hline Interesting, socially useful work & - & - & $.319^{*}$ & - & - & - & - \\
\hline
\end{tabular}

Note: ${ }^{*}-p \leq 0.05 ;{ }^{*}-p \leq 0.001$.

It was found that the attitude to alcoholic beverages in police officers has an inverse statistically significant correlation with the desire to structure work $\left(r_{p}=\right.$ $0.318 ; p=0.05)$ and a direct correlation with the desire for diversity and novelty in work $\left(r_{p}=0.280 ; p=0.05\right)$ (see Table 6). These indicators indicate that the attitude of police officers to alcohol reduces their need for organization, order, predictability, and control of professional activities and stimulates their desire for diversity and change.

It is determined that the attitude to the future of police officers has two statistically significant correlations: call, with motivation for influence and power $\left(r_{p}=-0.321 ; p=0.05\right)$ and direct, with motivation for interesting, useful work $\left(r_{p}=0.319 ; p=0.05\right)$. We can say that the police do not predict in the future to lead other people, but we want to benefit people and do interesting things. Continuing to the defined, we determined that in relation to the new, which was found in ingenuity, interest in everything new and immature, future orientation, police officers can motivate public recognition. This reasoning confirms the statistically significant direct correlation between the attitude to the new in police officers and their promotion to public recognition $\left(r_{p}=0.291 ; r=0.05\right)$. It was diagnosed that the police officers are willing to take risks through public understanding, which confirms a statistically significant direct correlation between risk attitudes and motivation for public recognition ( $r_{p}=0.376 ; r=0.001$ ). We can assume that such data indicate the presence of motivated risks in police officers as a means of adapting to occupational situations of danger (see Table 6).

The desire for self-development and selfimprovement has a statistically significant inverse correlation with the attitude of police officers to care and guidance $\left(r_{p}=-0.286 ; p=0.05\right)$. That is, police officers will not strive for self-development if they are constantly cared for and given instructions. There were statistically significant inverse correlations in the attitude of police officers to the rules and laws and their desire to work in a comfortable environment $\left(r_{p}=\right.$ $0.356 ; p=0.001)$ and the desire to influence and manage people $\left(r_{p}=-0.363 ; p=0.001\right)$ (see Table 6). In other words, compliance with the rules and the law reduces police demands on working conditions and their desire to control others.

\section{CONCLUSION}

The study revealed:

1. We can state that the professional activity of servicemen is motivated by high earnings and material rewards, diversity, the opportunity to learn something new, set bold, difficult goals and achieve them, the desire to do everything 
yourself, interesting, socially useful work. Police officers are motivated primarily by interesting, socially useful work, and secondly by the organization, predictability, feedback, and information that allows them to evaluate the results of their work. In addition, police officers are motivated by high earnings and the need to set bold, challenging goals and achieve them in a competitive process.

2. The attitude to courage in servicemen forms a statistically significant inverse correlation with the motivator of social contacts $\left(r_{p}=-0.305 ; p=\right.$ $0.05)$ and direct correlations with the desire to set and achieve goals $\left(r_{p}=0.289 ; p=0.05\right)$, the desire to self-improvement $\left(r_{p}=0.266 ; p=0.05\right)$ and motivation for interesting and useful work $\left(r_{p}\right.$ $=0.369 ; p=0.001$ ).

3. This reasoning confirms the statistically significant direct correlation between the attitude to the new in police officers and their promotion to public recognition $\left(r_{p}=0.291 ; r=0.05\right)$. It was diagnosed that the police officers are willing to take risks through public understanding, which confirms a statistically significant direct correlation between risk attitudes and motivation for public recognition $\left(r_{p}=0.376 ; r=0.001\right)$. We can assume that such data indicate the presence of motivated risks in police officers as a means of adapting to occupational situations of danger.

4. The desire for self-development and selfimprovement has a statistically significant inverse correlation with the attitude of police officers to care and guidance $\left(r_{p}=-0.286 ; p=\right.$ $0.05)$. That is, police officers will not strive for self-development if they are constantly cared for and given instructions. There were statistically significant inverse correlations in the attitude of police officers to the rules and laws and their desire to work in a comfortable environment $\left(r_{p}=\right.$ -0.356; $p=0.001$ ) and the desire to influence and manage people $\left(r_{p}=-0.363 ; p=0.001\right)$ (see Table 6). In other words, compliance with the rules and the law reduces police demands on working conditions and their desire to control others.

\section{REFERENCES}

Gray A. Motivation of military-professional activity of servicemen under contract, its psychological structure, and research methods, Bulletin of the Taras Shevchenko National University of Kyiv. Military special sciences. Issue № 2. 2015, pp. $39-43$

lasechko M., M. Kolmykov, V. Larin, S.Bazilo, H. Lyashenko, P. Kravchenko, N. Polianova, and I. Sharapa. (2020). Criteria for performing breakthroughs in the holes of radio electronic means under the influence of electromagnetic radiation, ARPN Journal of Engineering and Applied Sciences, 15(12), pp. $1380-1384$.

lasechko M., N. Sachaniuk-Kavets'ka, V. Kostrytsia, V. Nikitchenko, and S. lasechko (2020). The results of simulation of the process of occurrence of damages to the semiconductor elements under the influence of multi-frequency signals of short duration, Journal of Critical Reviews, 7(12), pp. 109 112. https://doi.org/10.31838/jcr.07.13.18

lasechko M., O. Palagin, V. Chimshir, S. Kaliakin, O. Grischenko, N Minko (2020). Formalized Model Descriptions Of Modified Solid-State Plasma-Like Materials To Protect RadioElectronic Means From The Effects Of Electromagnetic Radiation, IJATCSE. 9(5), pp. 8575-8579. https://doi.org/10.30534/ijatcse/2020/239952020

lasechko M., V. Larin, D. Maksiuta, S. Bazilo, and I. Sharapa (2020). The method of determining the probability of affection of the semiconductor elements under the influence of the multifrequency space-time signals, Journal of Critical Reviews, 7(9), pp. 569 - 571. https://doi.org/10.31838/jcr.07.09.113

lasechko M., V. Larin, O. Ochkurenko, S. Salkutsan, L. Mikhailova, and O. Kozak (2019). Formalized Model Descriptions Of Modified Solid-State Plasma-Like Materials To Protect RadioElectronic Means From The Effects Of Electromagnetic Radiation, IJATCSE. 8(3), pp. 393-398. https://doi.org/10.30534/ijatcse/2019/09832019

lasechko S., Puzyrnyi V., Puzyrna N., Kostiuk N., Bakhnovska I., and Litvinova, I. (2020). The Investigation Of Peculiarities Of The Occurrence Of Subjective Civil Rights In Registration Of A Patent. Journal Of Advanced Research In Law And Economics, 11(3), 844 - 849. https://doi.org/10.14505/jarle.v11.3(49).17

lasechko S., Stepanenko T., Korolova V., Makovetska N., Chernetchenko $O$. "Features of Legal Regulation Transplantations in Ukraine" JCR. 2020; 7(13): 430-432. Journal Of Critical Reviews, 7 (13), 430-432. https://doi.org/10.31838/jcr.07.13.76

lasechko, S., Bratsuk, I., Petrechenko, S., Kazanchuk, I., and Liashenko, R. (2020). Development of the Doctrine on Certain Personal Incorporeal Rights in European Countries. Journal Of Advanced Research In Law And Economics, 11(4), 1169-1174. https://doi.org/10.14505//jarle.v11.4(50).12

Ilyin E.P. Motivation and motives: textbook. Allowance. 2008, pp. 512.

Kuznetsov M.A. Human motivation: basic forms and patterns of functioning, Bulletin of the Kharkiv National Pedagogical University named after GS Frying pans. Psychology 2012, 44(1), pp. 116-137.

Piskunov S., M.lasechko, N. Minko, Yu. Dolomakin, O. Palagin, M. Musorina (2020). Taking Into Account The Correlated Errors Of Measurements When Estimating Parameters Of Object Trajectory At Mechanical Movement, IJETER, 8(9), pp. 5603 $-5606$. https://doi.org/10.30534/ijeter/2020/112892020

Research of personality structure (According to KK Platonov's "Personality Card") URL: https://studfile.net/preview/ 5263788/page:100/

Richie S., Martin P. Motivation management; lane. With English E.E. Lalayan; under the editorship of E. A. Klimov. YUPITI-DANA, 2009, pp.399. 
Rubinstein S.L. Fundamentals of general psychology, 2002, pp. 720.

Safin O.A. Psychology of the officer's professional activity. Kharkiv, NANGU, 2014, pp. 235
Smirnova O.M. Features of the motivational profile of the personality of police officers. Law and security. Issue 2 (69), 2018. pp. 43-50.

https://doi.org/10.32631/pb.2018.2.06

Received on 14-01-2021

Accepted on 17-02-2021

Published on 04-03-2021

https://doi.org/10.6000/1929-4409.2021.10.72

(C) 2021 Fedorenko et al.; Licensee Lifescience Global.

This is an open access article licensed under the terms of the Creative Commons Attribution Non-Commercial License (http://creativecommons.org/licenses/by-nc/3.0/) which permits unrestricted, non-commercial use, distribution and reproduction in any medium, provided the work is properly cited. 